\title{
COMPLAINTS AGAINST THE POLICE: EXPERIENCE OF THE COMNUNITY RIGHTS DIVISION OF THE PHILADELPHIA DISTRICT ATTORNEY'S OFFICE
}

\section{Louts B. SchWartz $\dagger$}

The Civil Rights Committee of the Philadelphia Bar Association, with the concurrence of the district attorney of Philadelphia, requested me to examine some of the district attorney's files relating to complaints of violence made against members of the Philadelphia Police Department. The district attorney's office opened its files to me and made its personnel available for consultation. I examined approximately twentyfive files. Sixteen of them, involving twenty complainants, were closely analyzed. The selection was unsystematic. Some were pulled at random from the filing case, but most were suggested by one person or another as matters on which controversy or publicity had centered. The period covered was mostly 1968-69, with a few files from 1970 .

Of the twenty-five files, nine, including four of those carefully studied, provided no basis for questioning the district attorney's judgment that prosecution would not have been warranted, no indication that further investigation would have been in order, and nothing of any special interest in evaluating the entire process of handling complaints. This is not to say that the complainant's story was false. Often it was circumstantial and plausible, but that is not enough to warrant prosecution of a policeman when the events reported might be interpreted in several ways, the complainant is not corroborated, and the police plausibly contradict the complainant. Four other files seemed clearly appropriate for prosecution. No prosecutions had occurred. In classifying the cases as prosecution-worthy, I do not mean that convictions would have been obtained. The difficulty of persuading judges and juries to rule against the police in such matters is illustrated by the outcome of a very recent prosecution which the district attorney did institute against two policemen for the fatal shooting of a boy. The seemingly strong case was dismissed on preliminary hearing after testimony by thirty-seven witnesses. ${ }^{1}$ In the remaining cases the prosecutor could not be faulted for declining prosecution on the existing state of the record, but the files revealed disturbing shortcomings in the whole process of evaluating complaints, as elaborated below.

†Benjamin Franklin Professor of Law, University of Pennsylvania.

1 Phila. Evening Bulletin, May 22, 1970, at 1, col. 1. 
No conclusion can be drawn from such a survey as to the frequency of particular practices either in the district attorney's office or the police department. The files are, however, quite revealing as to the nature of the problems confronting both agencies. I believe the following conclusions to be justified.

I. The District Attorney's Office Has Not Been and, in the Nature of Things, Could Not Be, an Effective Instrument for Controlling Police Violence

\section{A. Confict of Interest}

It is in a hopeless conflict of interest position. Complaints of police violence almost always arise in cases where the police are making charges against the complainant-for example, assault and battery against a policeman, resisting arrest, disorderly conduct-in addition to the independent offense for which the police sought to arrest complainant (hereinafter $C$ ). At the same time $C$ is charging the police with, for example, beating or excessive violence. The district attorney is cast as prosecutor of $C$ on the first set of charges with the aid of the police and as prosecutor of the police with the aid of $C$ on the second set of charges. The conflict of interest is actually institutionalized in the structure of the district attorney's office, where a special Community Rights Division, concerning itself with C's position, frequently finds itself arrayed against other assistant district attorneys. The Community Rights Division seeks dismissal of charges or postponement of the trial pending investigation of C's complaint, while the assistant district attorney charged with prosecuting the defendant is naturally inclined to go forward in reliance on the police testimony. It is fair to say that the district attorney's office as a whole and its upper echelons, to which the Community Rights Division reports, are basically oriented towards the police. It could hardly be otherwise in view of the daily cooperation essential between the police and the prosecutor. It is absurd to expect a district attorney's office to secure a conviction of $\mathrm{C}$ on the testimony of police officers for some substantive offense, like a gang shooting, and then to turn around and prosecute the police witnesses on the ground that they unnecessarily beat $C$ (and lyingly denied it). To reverse the order of trial for two such cases would be even more ridiculous, putting the district attorney in the position of using unbelievable policemen to prosecute accused persons.

The foregoing is not to be understood as a criticism of the existence or operation of the Community Rights Division. On the contrary, the establishment and continuance of such a division within the district 
attorney's office is essential so long as we have no truly independent check on police behavior. Without the Community Rights Division the conflict of interest in the district attorney's office would be merely less visible, and no one would be expressly charged with the duty of attending to the public interest in controlling abusive police behavior. Given the limits within which it is compelled to operate, the Community Rights Division can do and has done a useful job when staffed with a courageous and persistent assistant district attorney.

The conflict of interest which disables the district attorney from operating effectively on the police violence problem is occasionally dramatized by publicized incidents : on one occasion the first assistant district attorney reportedly seated himself for a time at the defense table along with Police Commissioner Rizzo in a trial of two policemen for assault and battery; on another occasion, Commissioner Rizzo, referring to the district attorney's institution of assault charges against the policemen, said "Specter will rue the day he took up this one." 2

\section{B. Police Investigation.}

The Community Rights Division is almost wholly dependent on police investigation. Prior to January 1969, by agreement between the district attorney and the police department, complaints made to the Community Rights Division had to be referred in the first instance to the police department for investigation, and nothing was done until the police department reported. Since that time, selected complaints have been looked into by the Community Rights Division while the police department is investigating. Another aspect of the agreement is still in force: no policeman involved in a complaint will speak to anyone outside the police department except with the approval of his superiors. There is no indication in the files that such approval was ever sought or given. Many files are closed with a notation that the Community Rights Division concurs in the police department reports and finds "no acceptable evidence of any police mistreatment." Without suggesting that all or any of the police reports are unreliable, it is clear that the district attorney's office cannot effectively police the police when its major source of information is the police department.

\section{Policies Impeding Checks on the Police}

Effective response by the district attorney's office to complaints against the police is further impaired by several policies of the office which, although justifiable from the point of view of limiting prosecution of policemen to cases likely to be won, undercut the deterrents to police misbehavior. These policies are: (i) the "serious injury" policy;

2 Id., April 3, 1970, at 1, col. 1. 
(ii) the "complainant's satisfaction" policy; and (iii) the "mutual release" policy.

The serious injury policy means that the district attorney will rarely move in cases where the police may have beaten a citizen without cause if the citizen did not lose teeth or suffer some severe damage preferably established by hospitalization records. This is understandable in view of the necessary police involvement in rough encounters where minor physical violence is expectable: it will be difficult to persuade a judge or jury beyond a reasonable doubt that a policeman employed excessive or unprovoked force, against the policeman's sworn denial, absent tangible evidence of substantial damage to $C$. But the result is that the great majority of complaints which might merit discipline or reprimand, if not criminal prosecution, automatically drop out of the district attorney's consideration.

The "complainant's satisfaction" policy is manifested in the disposition of complaints on a nonprosecution basis whenever $C$ will be satisfied if the policeman receives a reprimand or short-term suspension. Sometimes a file gives evidence of an affirmative effort by the assistant district attorney to secure agreement by $\mathrm{C}$ to some such compromise or settlement. This process may end up with a "mutual release" understanding in which both sides drop their charges against each other. Again, the practice is understandable from the point of view of a busy prosecutor seeking to clear his docket of as many cases as possible. But the adverse consequences and social cost of the practice are excessive: cases which should result in some sanctions against the police are washed out without even a reprimand to the policeman. An incentive is established for the policeman involved in any complaint to file charges against $\mathrm{C}$ for bargaining purposes, and sometimes such charges are filed only after the private citizen has complained. From the point of view of complainants, minority press, and civil liberties groups, the credibility of both the district attorney and the police department suffers when the law enforcement authorities seek to trade off charges made by the police and charges made against the police. In one case coming to my attention, there was pending a proposal to drop apparently well-supported charges that $C$ fired shots at policemen in the course of a gang fight if he would drop well-supported charges of police brutality. The public interest would require that both charges be pursued. The district attorney's office is not in a position to handle both sides.

\section{The Private Warrant}

The law of Pennsylvania contemplates institution of criminal proceedings without the approval or participation of the district attor- 
ney. This is done by the private complainant securing a warrant from a magistrate ${ }^{3}$ on the basis of an affidavit setting forth the facts of the alleged criminal behavior. Two practices have grown up to restrict the use of private warrants: there is a substantial charge for issuance of such warrants, and the magistrates decline to issue them when not previously approved by the district attorney. The district attorney's approval can also relieve the applicant from the necessity of paying for the warrant. Considering the responsibilities of the district attorney to represent the state in carrying forward public prosecutions, these restraints make sense when applied to ordinary minor offenses, transitory family "assault" charges, and the like. They do not make sense as applied to complaints against the police, or indeed against any public official with whom he may or may not have political alliance. The district attorney, with the conflict of interest previously described, should not be in the position of making preliminary judgments either favorable or unfavorable to the complainant. Such judgments should be made by the magistrate unencumbered by the prosecutor's prejudgment. Nor should citizens have to pay for the privilege of complaining against the authorities. It should be quite sufficient, for example, that any member of the bar associates himself with the complaint. And if that complaint survives scrutiny by the magistrate (a scrutiny by no means hostile to the police), that member of the bar might well be allowed to proceed as special prosecutor or "private attorney general"-an arrangement that is quite familiar in some other areas of law enforcement. ${ }^{4}$

\section{Typical Shortcomings in Investigation of Complaints Against the Police}

\section{A. Police Investigation of Police Is Not and Cannot Be Neutral}

It tends to be defensive of the police and slanted against complainants. The police investigations studied varied in quality and thoroughness. Some appeared to be complete and impartial; others certainly did not. The point is not that investigating officers are dishonest or not trying to do a good job in most cases. It is simply that the same conflict of interest which frustrates a fair and credible disposition of citizen complaints by the district attorney's office operates even more strongly when the police department investigates itself on complaints filed by persons whom the police department has already

3 Since January 1969, the functions of magistrates have been carried on by judges of the municipal court. Subsequent references to magistrates in this paper should be understood as referring to magistrates in the broad sense, including judges.

4 Pa. Stat. tit. 19, $\$ \$ 1235,1261$ (1964). 
identified as violent criminals, some with long previous records. The investigating officers or the commanding officers who report on the incident are often superiors who have previously given very favorable performance ratings to the subject policeman and who are likely to continue to be in daily work relationship with him. Only the most blatant offense, supported by incontrovertible evidence, could induce the investigators and superiors to abandon their fellow officer. The illustrations below are drawn from the activities of both the Community Rights Division and the police investigators.

\section{B. An Unusually Heavy Initiative and Burden of Proof Is Placed on the Complainant}

When a complaint of criminal conduct is made against anyone other than a policeman, a positive effort is made to follow up, find supporting witnesses, and so forth. In the case of complaints against the police, the bulk of the file is made up of statements by police witnesses. In one file, the district attorney investigator, asked by C's lawyer to trace an important witness through his automobile registration, declined to aid in finding "your witnesses." In another file, the police report failed to include any interview with $\mathrm{C}$, taking the position that he was "unavailable" because he was held in the House of Detention. Private witnesses for $\mathrm{C}$ are invited, and sometimes urged, to come in to make a statement, but a failure to do so is likely to be taken as indicating C's bad faith or lack of interest, either of which warrants dropping the matter. But in fact the failure to pursue the complaint may manifest fear or distrust of the law enforcement officials. Himself a defendant, $C$ must be aware that anything he says to the police may turn up as evidence against him at his trial. In one file, the father of a complainant declined to come in unless he could be accompanied by a lawyer. The father had himself been arrested, without basis, at the time of the incident involving his son, and had reason to believe that statements he had previously volunteered were being misinterpreted and used against his son.

\section{Witnesses Against the Police Are Sometimes Examined in a Hostile Atmosphere and Their Testimony Unfairly Deprecated}

In one case, $\mathrm{C}$ was examined by the investigator in the presence of the accused policemen, with the explanation that they had a "right to confront the witnesses against them." It is perfectly clear that such a right exists only in the court where a trial is taking place, and that the circumstances of this interview could only have been intimidating. In 
another file, C's statement that money had been taken from his wallet by a policeman was dismissed on the basis that he had given "contradictory" acounts. My own appraisal of the transcript of his interrogation is that, although there were superficial inconsistencies probably arising from the hostile questioning, his story liung together well enough; at the very least, there was enough there to warrant seeking out certain available disinterested witnesses. This was not done.

Another file included an examination of one of several disinterested women who had observed the police brutality in the course of an arrest; the interrogator pressed her for a concession that, even if the police had used excessive force, she did not think they ought to be prosecuted or be prejudiced in their employment. In several files, the mental competence of $C$ was impugned without adequate justification. $C$ is likely to be characterized as a mental defective, not worthy of credence, on the basis of a passing remark by a member of his family, or because he has been treated by a psychiatrist. In two such instances, I was surprised on reading the transcript to find the responses to the investigator's questioning entirely coherent and intelligent. Complainants are sometimes addressed by first name during interrogation, a disrespectful practice calculated to insult.

\section{The Lie Detector}

The police never take lie detector tests, and always insist that $\mathrm{C}$ take one. When $\mathrm{C}$ agrees, the test is administered by a police lieutenant under circumstances not disclosed in the files. His unfavorable report is entirely summary: $C$ appears to be lying. There is no description of the test or the data that would make possible any independent evaluation, although it is well-known that interpretation of the physical data plays a large role in lie detection. The one case observed in which the police-administered lie detection test was favorable to $\mathrm{C}$ involved a very "well connected" white college boy whose story was obviously unassailable and corroborated by demonstrably false entries by the accused policemen in their log-book.

Refusal by policemen to take lie detector tests, even those administered by the police department itself, results from the refusal of the Fraternal Order of Police to supply free counsel to an accused policeman if he submits to such a test. An individual policeman is certainly entitled to refuse to take a test, just as anyone is. But the collective effort of the Fraternal Order of Police to penalize him if he chooses to take the test seems to have only one conceivable purpose: to prevent any unfavorable inference that might be drawn if some policemen readily took and "passed" the test while others declined. 
In contrast, the pressure on complainants to take the test mounts to the point of official impropriety. In one case, already referred to above, where $\mathrm{C}$ was interviewed in the presence of two police officers he accused, questions were first put to the officers as to their willingness to take lie detector tests "if the Fraternal Order of Police doesn't object." They of course agreed, knowing, as did the investigator, that the Fraternal Order of Police does object. Their false willingness was then used to persuade $C$ to take the test.

\section{E. Restricted Access to Police Witnesses}

While the police investigators are free to interview anyone in the course of the investigation, the policemen involved in the incident are under orders not to talk to anyone outside the police department while the police investigation is pending. This is pursuant to a formal agreement between the district attorney's office and the police department, and it applies even to interviews by the Community Rights Division of the district attorney's staff. Among the results of this restraint is the inability of anyone other than the police to get a freshly recalled account of what happened from the police point of view. By the time anybody else gets into the picture the police story has solidified, contradictions ironed out, and the opportunity has been created for the exertion of informal pressures among police officers themselves against saying anything prejudicial to a fellow officer. One cannot know for certain that any such thing occurs, but the community has cause for suspicion when an officially-sponsored practice is so favorable to "whitewash." The arrangement is perilously close to that condemned by the Supreme Court of Pennsylvania in Lewis v. Lebanon County Court of Common Pleas." In that case, District Attorney Lewis refused to consent to defense attorney's interviewing an FBI expert. This blocked access to the witnesses because the FBI had a rule that its agents would not talk to a defense attorney without the district attorney's consent. The Lebanon court then ordered the district attorney to consent, and the supreme court affirmed this action, Chief Justice Bell dissenting. Mr. Justice Jones's opinion for the court declared :

We are aware of no authority in the law which gives the district attorney the right, in general, to deny defense counsel access to the Commonwealth's witnesses. Under the ethical standards of our profession, in the absence of special circumstances to which we hereinafter allude, the consent of the district attorney should not be necessary to insure defense counsel's right to interview a witness prior to the trial. The 
primary purpose of a district attorney is not to convict, but to see that justice is done.

. . . [I]f it is possible that Agent Stombaugh might have evidence which is favorable to the defendant, then the suppression of that evidence may well constitute a denial of due process.

It has been vigorously urged that there is a substantial difference between affirmatively ordering a witness not to talk with defense counsel, and merely advising the witness that the prosecution does not consent to the interview. We are not persuaded. In the majority of instances, as in the case at bar, the effect of the prosecutor's expressed disapproval would be to prevent defense counsel from speaking with the witness until the witness testifies at trial. This result is unsatisfactory. We are concerned with the interference by a district attorney with the right of a defendant to interview an otherwise willing witness.

A minimum reform in this area would be the cancellation of the agreement and order restricting access to police witnesses. Together with the lowering of the private warrant barrier to prompt public hearings before a magistrate, this would do much to open these unhappy affairs to public view promptly after the events.

\section{F. Internal Police Discipline: Vague Charges and Petty Penalties}

The files provided some indications of areas for improvement in internal disciplinary proceedings before the Police Board of Inquiry. There is, in the first place, need for more precisely defined charges. In the few cases resulting in disciplinary sanctions against policemen, the charges were likely to be "conduct unbecoming an officer" or "disobedience of standing orders." Because these categories can include any kind of misbehavior from the most serious to the most trivial, conviction on such charges tells the public very little about the nature of the wrongdoing, and makes it easy to impose trivial penalties. In no file was any penalty imposed beyond ten day's suspension, although in one case the policeman was allowed to take a medical retirement on the basis of psychiatric reports that were conflicting as to whether his violent behavior was due to an identifiable mental illness or to chronic irritation over social and racial conflicts. As a penalty for serious misbehavior, a short suspension from duty is virtually meaningless. It amounts to a requirement that the officer take part of his vacation at the time of the suspension. He does not even lose any pay. In one

6 Id. at $301-03,260 \mathrm{~A} .2 \mathrm{~d}$ at 188 . 
file, an improper and utterly baseless arrest, unjustified clubbing, and falsification of the patrol $\log$ resulted in such a short suspension. One might have expected the separation of such policemen from the force if the public and the courts are to have confidence in police testimony.

Among the precise categories of internal disciplinary charges on which policemen should be tried, covering the most frequent classes of incidents, would be: improper stop or other confrontation, illegal arrest, illegal search, excessive force in effecting arrest, illegal attack upon a person in custody, theft from a person in custody, false entry in official reports.

\section{G. Improper Confrontations}

The files reveal that a substantial proportion of the encounters leading to charges of lawless violence by the police begin with confrontations which a well-trained policeman should avoid:

(1) A black motorist is double-parked outside a store. A police car pulls up, and the officer queries the double-parking. The motorist explains that he has stopped momentarily to let his wife out and give her money for shopping. Sharp words are exchanged, followed by arrest, blows, and eventual charges of disorderly conduct, resisting arrest, assault and battery on a policeman. The file does not make it clear, but we may assume that the motorist provoked the police initially by loud and disrespectful language. At that point the police were faced with a choice-to dispose of the matter by coolly advising the motorist he must move the car promptly, or to subject the motorist to an arrest for "disorderly conduct," sure to be resented hotly as an escalation of the unpleasantness over a trifle. The wrong choice leads in the direction of violence.

(2) Police stop to question two black men pushing an automobile on a lot. They are told that the automobile has just been purchased by the father and brother of one of them, the purchasers having just gone off to a notary to conclude the formalities. The father and brother return with the seller, a white man, who confirms that there is no occasion for police concern. The police nevertheless insist on "identification." According to the police account itself, the brother became indignant, loud, and disrespectful, but not profane or physically aggressive. The police then made the critical decision, to "take the whole job [that is, all four men] into the district where we can settle this quietly." The brother then walked away towards his own car and drove off. He was followed by police cars, stopped, and severely beaten in the course of arrest. The arresting police and, later, the police investigator in his report, indicated that the arrest was proper on the 
ground that complainant walked away from the police when they had indicated they proposed to take him into the district "for investigation."

The file is an example of unwarranted police insistence on citizens responding to inquiries. Without passing on the merits of the controversy over the beating (was it a savage, punitive beating following submission to arrest, as reported by some independent witnesses, or force necessary to overcome resistance?), the incident plainly grew out of improper police persistence in a confrontation, and erroneous police views that "boisterous" expression of resentment and peaceable departure when the police desire to continue questioning amount to offenses for which they may and should arrest.

(3) A group of boys congregated on a street corner are ordered away by a policeman, who cites the city curfew ordinance although it is nearly an hour before curfew time. Complainant responds that he is eighteen and therefore not subject to the ordinance. The policeman asks for documentary identification showing age. The boy has none but points to his grandmother standing at the door of her home a few feet away. Without inquiry of her, the police take the boy into custody. At a place not on the route from the place of apprehension to the district station, the boy is beaten severely, losing three teeth. This case resulted in a five-day suspension of the police. Like the previous examples, it appears to be an outgrowth of unwarranted police interference and of the view of some policemen that any defiance of the police constitutes disorderly conduct.

\section{H. Inadequate Records and Public Disclosure Concerning Complaints Against the Police}

The files touch this problem only incidentally. They include some press clippings expressing dissatisfaction, or correspondence with complainants' lawyers obviously uninformed about the results of investigations. Fuller disclosure would often dispel suspicion about the handling of complaints when, for example, it would be plainly improper to prosecute and impossible to convict policemen on the unsupported testimony of a complainant of doubtful character.

Among the things that appear to be needed or desirable would be a central public registry and docket of complaints. This would include complaints lodged with any agency, public or private. Under the present system, complaints tend to flow to agencies from which complainants are most hopeful of getting action. Segments of the community having most confidence in the police are more likely to take their complaints directly to the police department. Others seek the aid of the Civil Liberties Union, the Human Relations Commission, the 
NAACP, or Philadelphians for Equal Justice. Announcement that the district attorney's office is concerned will swell the flow of complaints there; realization that only "serious injury" cases can be considered for prosecution, or disappointment over delay and nonprosecution, tends to divert complaints elsewhere. Dispersal of complaints makes it hard to get accurate measurement of the total number of complaints, or to identify officers and districts against which complaints are concentrated.

A central docket would also expose delay and record ultimate disposition of complaints. The district attorney files often conclude with a memorandum closing the case so far as concerns the sufficiency of the evidence to support a prosecution, but without any judgment, recommendation, or communication to the police department or the complainant. Although this is perhaps understandable in view of the technical limitation of the district attorney's authority-he is responsible only for the decision to prosecute or not prosecute-it leaves the issue of the propriety of the police behavior unresolved, a highly unsatisfactory situation from the point of view of the public and the complainant.

\section{ConcLuston}

As indicated earlier, relaxation of controls over private warrants and elimination of restraints on access to police witnesses would contribute to prompt public airing of complaints against the police. However, one should not rely entirely on preliminary hearings on criminal charges before magistrates. There are relationships between magistrates and the police that would prevent this from being wholly satisfactory and, in any event, the criminal law can play a role only in the worst cases. It would probably be helpful if a complainant had an opportunity to intervene within the police department itself at some point before the department has made up its mind regarding a complaint. Such an opportunity to present his side of the matter in a public hearing before the Police Board of Inquiry, or other quasijudicial body within the police department, as part of the police inquiry rather than after its conclusion, might well reduce delay, give top departmental officials a better opportunity to appraise the complainant's case and the seriousness of the policeman's transgression, if any, and enhance public confidence in police procedures. The benefits of such a procedure would be maximized if the police tribunal included a recognizably independent person, perhaps rotated from a panel suggested by affected interest groups.

In the final analysis, however, achievement of full confidence in the law enforcement authorities will probably require an independent 
agency to hear and dispose of complaints, an agency having its own investigators, subpoena power, and access to the courts. Whether this agency would develop as a special unit to hear complaints against the police, or with broader jurisdiction to hear complaints against public officials generally (the "ombudsman"), or in the form of an independent board of public safety to supervise police and other safety operations, as the board of education supervises the school system, is a question beyond the scope of this research. 